Article

\title{
Arsenic Removal from Water by Adsorption onto Iron Oxide/Nano-Porous Carbon Magnetic Composite
}

\author{
Sahira Joshi ${ }^{1}$, Manobin Sharma ${ }^{1}\left(\right.$, , Anshu Kumari ${ }^{2}$, Surendra Shrestha ${ }^{3, *}$ and \\ Bhanu Shrestha $4, *$ (D) \\ 1 Department of Applied Sciences, Pulchowk Campus, IoE, Tribhuvan University, Lalitpur 44700, Nepal \\ 2 Tri-Chandra Multiple campus, Tri-Chandra College, Tribhuvan University, Ghantaghar, \\ Kathmandu 44605, Nepal \\ 3 Department of Electronics \& Computer Engineering, Pulchowk Campus, IoE, Tribhuvan University, \\ Lalitpur 44700, Nepal \\ 4 Department of Electronics Engineering, Kwangwoon University, Nowon-gu, Seoul 01897, Korea \\ * Correspondence: surendra@ioe.edu.np (S.S.); bnu@kw.ac.kr (B.S.); \\ Tel.: +977-1-443-1447 (S.S.); +82-2-940-8626 (B.S.)
}

Received: 1 August 2019; Accepted: 5 September 2019; Published: 7 September 2019

\begin{abstract}
This study aimed to develop magnetic $\mathrm{Fe}_{3} \mathrm{O}_{4}$ /sugarcane bagasse activated carbon composite for the adsorption of arsenic (III) from aqueous solutions. Activated carbon (AC) was prepared from sugarcane bagasse by chemical activation using $\mathrm{H}_{3} \mathrm{PO}_{4}$ as an activating agent at $400{ }^{\circ} \mathrm{C}$. To enhance adsorption capacity for arsenic, the resultant $\mathrm{AC}$ was composited with $\mathrm{Fe}_{3} \mathrm{O}_{4}$ particles by facile one-pot hydrothermal treatment. This method involves mixing the AC with aqueous solution of iron (II) chloride tetrahydrate, polyvinyl pyrrolidone (PVP), and ethanol. Batch adsorption experiments were conducted for the adsorption of As (III) onto the composite. The effects of $\mathrm{pH}$, adsorbent dosage, and contact time on the arsenic adsorption were studied. The result showed that the composite could remove the arsenic from the water far more effectively than the plain AC. The highest percentage of arsenic removal was found at $\mathrm{pH}$ at 8 , adsorbent dose of $1.8 \mathrm{~g} / \mathrm{L}$, and contact time of $60 \mathrm{~min}$. Langmuir and Freundlich adsorption isotherm was used to analyze the equilibrium experimental data. Langmuir model showed the best fit compared to the Freundlich model with a maximal capacity of $6.69 \mathrm{mg} / \mathrm{g}$. These findings indicated that magnetic $\mathrm{Fe}_{3} \mathrm{O}_{4} /$ sugarcane bagasse AC composite could be potentially applied for adsorptive removal of arsenic (III) from aqueous solutions.
\end{abstract}

Keywords: sugarcane bagasse; activated carbon; magnetic composite; arsenic adsorption

\section{Introduction}

Arsenic (As) contamination of groundwater is of major concern in the various parts of the world, where the water supply is primarily dependent on groundwater. A higher concentration of arsenic in groundwater has been reported in several countries, including Argentina, Chile, Mexico, China, Argentina, USA, Hungary, Australia, Switzerland, Cambodia, Thailand, Vietnam, Mongolia, Taiwan, Pakistan, as well as in the Indian State of West Bengal, Bangladesh, and Nepal [1]. In Southeast Asia, millions of people are exposed to groundwater with As concentrations higher than the WHO guideline value of $10 \mu \mathrm{g} / \mathrm{L}$ [2]. The highest concentration of As is being found in India $(0.003-3700 \mu \mathrm{g} / \mathrm{L})$, followed by China $(220-2000 \mu \mathrm{g} / \mathrm{L})$ and Bangladesh $(10-1000 \mu \mathrm{g} / \mathrm{L})$. The largest population at risk is in Bangladesh, followed by West Bengal in India [3].

In Nepal, nearly $47 \%$ (11 million) of the total population inhabits in southern lowlands of Nepal (the so-called Terai), and over $90 \%$ of the population draws groundwater from tube wells for drinking, household use, and irrigation. The possibility of arsenic contamination in tube well water of some 
districts of Terai region was first identified in 1999. Later studies also documented that the region of As contamination extends into 24 districts in Nepal, including 20 districts of Terai region and four districts of the hilly region [4]. The most severe As contamination is prevailing in Nawalparasi, Bara, Parsa, Rautahat, Rupandehi, and Kapalivastu districts [5]. It is estimated that 0.5 million people in Terai are at risk of consuming water with As level greater than $50 \mu \mathrm{g} / \mathrm{L}$, while 3.5 million have been exposed to As levels between 10 to $50 \mu \mathrm{g} / \mathrm{L}$ [4]. Arsenic contamination of groundwater of Nepal is mainly of natural (geogenic) origin, and its elevated concentrations are considered to be caused by reductive dissolution of ferro-oxyhydroxide [6].

Arsenic can exist in four oxidation states: $-3,0,+3$, and +5 . In natural water, As exists primarily as oxyanions representing two oxidation states: arsenite $(+3)$ and arsenate $(+5)$. Usually, inorganic As is more toxic than organic As. Inorganic As is mostly found in water as trivalent arsenite or pentavalent arsenate. Arsenite (As (III)) is more mobile and toxic than the arsenate (As (V)) due to its tendency to react like a soft metal with thiols. Solubility of Arsenic in ground water depends on $\mathrm{pH}$, redox conditions, temperature, and solution composition. [7,8]. The reduced form (As(III)) is normally found in groundwater under anaerobic conditions, while arsenate, the oxidized form (As (V)), is found in surface water under aerobic conditions. At near neutral $\mathrm{pH}$, the predominant species are $\mathrm{H}_{2} \mathrm{AsO}_{4}-$ and $\mathrm{HAsO}_{4}{ }^{2-}$ for arsenate and uncharged $\mathrm{H}_{3} \mathrm{AsO}_{3}$ for arsenite. In the Terai region of Nepal, groundwater appears mostly to be neutral to alkaline with a $\mathrm{pH}$ range of 6.1-8.1. Moreover, the variations of redox potential (Eh) between -0.2 to $-0.11 \mathrm{~V}$ also suggested fairly reduced conditions in the aquifers [9]. Hence, arsenite, the reduced trivalent form (As (III)), is mostly present in the groundwater of the Terai region.

Long-term exposure to arsenic from drinking-water can cause diverse types of cancers, including skin, lungs, urinary bladder, kidney liver, and prostate cancers. The non-cancerous effects that are associated with arsenic exposure include hyperkeratosis, pigmentation changes, cardiovascular diseases, hypertension, and respiratory, neurological, liver, and kidney disorders, as well as diabetes mellitus [10]. To prevent health problems associated with As, an effective technique for the removal of As from groundwater before using it for drinking purpose is very essential.

Several methods have been applied for the removal of As from water which include oxidation [11], alum/iron coagulation [12,13], adsorption/ion-exchange (activated alumina, iron-coated sand, and ion-exchange resin) [14,15], membrane filtration [16], reverse osmosis [16]. Conventional methods, such as ion exchange, reverse osmosis, and membrane filtration, are not feasible for large applications due to low efficiency, generation of secondary pollutants, and high cost. In developing countries, precipitation and adsorption methods are widely used for As removal. Precipitation method requires a large amount of chemicals and creates a volumetric sludge as Arsenic III sulfide, calcium arsenate, or ferric arsenate. So, the adsorption method is the method of choice. The method is simple, cost-effective, and efficient with minimum waste production and can be applied in water containing a trace amount of pollutants [17]. A wide variety of adsorbents has already been studied, including kaolinite, montmorillonite, activated alumina, titanium dioxide, iron hydroxide, zero-valent iron, chitosan, etc. $[18,19]$. Among them, iron-based magnetic material, particularly iron oxide, is commonly used as adsorbent due to their higher magnetic character and lower cost $[20,21]$. However, its widespread application for As removal is limited because it is very bulky, highly amorphous, and flocculant. To deal with the problem, research efforts are being focused on creating media supporting iron oxide. In this regard, different porous supports have been employed, such as activated carbon, clay, zeolite, polymer, and biopolymer [21]. Activated carbon (AC) has been proven ideal support because of its stable and variable pore structure. Use of iron oxide-loaded activated carbons (ACs) for As removal from contaminated water has shown the promising results [17,22]. During adsorption, the aqueous oxyanions (such as $\mathrm{H}_{2} \mathrm{AsO}_{4}{ }^{-}$and $\mathrm{HAsO}_{4}{ }^{2-}$ ) undergo a ligand exchange reaction with iron speciation on the carbon surface and form an inner-sphere surface complex [23]. After adsorption, the AC composite can also be separated from the medium by a simple magnetic 
process [17]. The efficiency of As removal depends upon both the amount of iron loading and dispersion and surface accessibility of this iron oxide within the porous AC.

Iron oxide/AC magnetic composite was fabricated for arsenic adsorption from aqueous solution by Yao et al., 2014 [17]. Wannahari et al. [24] synthesized sugarcane bagasse derived nanomagnetic adsorbent composite for the removal of $\mathrm{Cu}$ (II) from aqueous solution. Kakavandi et al. [25] studied the adsorption of $\mathrm{Pb}$ (II) onto $\mathrm{Fe}_{3} \mathrm{O}_{4}$ /activated carbon composite. Removal of dye from aqueous solution using $\mathrm{Fe}_{3} \mathrm{O}_{4}$ /activated carbon nanocomposite was studied by Gholamvaisi et al. [26]. Iron oxide/AC composite can remove boron and organics from wastewater [27]. Similarly, it has also been found that iron oxide/AC composite is useful in removing different kinds of contaminants like trinitrophenol, phosphate, atrazine, lead, arsenic, mercury, and methylene blue dye from aqueous solutions [28-33]. The obtained results indicate that the prepared magnetic nanocomposite of iron oxide and AC is one of the efficient adsorbents for the removal of these pollutants from aqueous solution. The high efficiency of magnetized adsorbents is due to their easy control and fast separation by direct application of a magnetic field.

For the synthesis of AC, the use of agricultural wastes is being considered as a good alternative source material because of their abundant supply at no or low costs. They are lignocellulosic materials and comprised of about $10-25 \%$ lignin, $20-30 \%$ hemicellulose, and $40-50 \%$ cellulose [34]. Several agricultural wastes, including sugarcane bagasse, cottonwood, and coconut shell, are considered for the production of carbon composites. Agricultural wastes, such as sugarcane bagasse [35], coconut shell, cottonwood [36], and rice husk [37], have been reported to produce carbon composites. Sugarcane (Saccharum officinarum L., Gramineae) bagasse, a by-product of the sugarcane industry, is another source of lignocellulosic raw material and composed of $39.5 \%$ cellulose, $29.9 \%$ hemicellulose, and $25.1 \%$ lignin content (wt \%, dry basis) [38]. In Terai, Nepal, sugar manufacturing factories dispose of tons of sugarcane bagasse to the surrounding region [39]. The improper disposal of these wastes can lead to inconvenience, environmental pollution, and, consequently, health hazards in that region. Utilizing sugarcane bagasse for the preparation of carbon composite could be a promising approach to produce efficient, abundant, low-cost adsorbent for As removal. It may be also a solution for the agricultural waste problems in Nepal, particularly in the Terai region. Hence, the objective of this study was adsorptive removal of As (III) from aqueous solutions by adsorption onto magnetic $\mathrm{Fe}_{3} \mathrm{O}_{4}$ / sugarcane bagasse AC composite.

\section{Experimental}

In this section, we presented a concise and precise description of the outputs based on the experiment, and through these experimental results, we concluded this study.

\subsection{Materials Used}

All the chemicals used in the study were of analytical grade. Sugarcane bagasse was collected from food industry, Kathmandu, Nepal. Eighty-five percent $(w / w)$ orthophosphoric acid (Fisher Scientific, New Delhi, India) was used. Iron (II) chloride tetrahydrate $\left(\mathrm{FeCl}_{2} \cdot 4 \mathrm{H}_{2} \mathrm{O}\right)$ (Samchun Chemicals, Seoul, Korea), ammonium hydroxide $\left(\mathrm{NH}_{4} \mathrm{OH}, 25 \% \mathrm{NH}_{3}\right.$ in water) (Fisher Scientific, New Delhi, India), arsenic trioxide $\left(\mathrm{As}_{2} \mathrm{O}_{3}\right)$ (G.S. Chemical Testing Lab and Allied Industries, New Delhi, India), and Polyvinylpyrrolidone (PVP, MW-5800) (Alfa Aesar, Seoul, Korea) were used. The stock solution of As (III) was prepared from arsenic trioxide $\left(\mathrm{As}_{2} \mathrm{O}_{3}\right)$ and was diluted to the desired concentrations. The nitrogen gas of ultra-high pure (UHP) was used to create an inert atmosphere during carbonization. All the solutions in this study were prepared using distilled water.

\subsection{Preparation of Activated Carbon}

Ten grams of dried, crushed, and powdered sugarcane bagasse was mixed with $\mathrm{H}_{3} \mathrm{PO}_{4}$ in the ratio of 1:1 by weight and an appropriate volume of distilled water was added. Then, the mixture was stirred with a glass rod at $700{ }^{\circ} \mathrm{C}$ until partially dried and dehydrated at $110^{\circ} \mathrm{C}$ for $24 \mathrm{~h}$ in an air oven. 
After drying, the sample was kept in a horizontal tubular furnace and carbonized at $500{ }^{\circ} \mathrm{C}$ for $3 \mathrm{~h}$, under a continuous nitrogen flow of nitrogen $(75 \mathrm{~mL} / \mathrm{min})$. The AC thus prepared was allowed to cool and washed several times with warm distilled water till free from acid. The AC was then dried at $110^{\circ} \mathrm{C}$ for $24 \mathrm{~h}$ and sieved to obtain the particles of size $106 \mu \mathrm{m}$.

\subsection{Synthesis of Adsorbent ( $\mathrm{Fe}_{3} \mathrm{O}_{4} / \mathrm{AC}$ Composite)}

Magnetic AC composite was prepared by a facile one-step hydrothermal process. In the process, $800 \mathrm{mg}$ of hydrated ferric chloride $\left(\mathrm{FeCl}_{3} \cdot 6 \mathrm{H}_{2} \mathrm{O}\right)$ was dissolved in $40 \mathrm{~mL}$ of distilled water. Then, $2 \mathrm{~mL}$ of ammonia solution was added to the solution under constant stirring for $45 \mathrm{~min}$ with a magnetic stirrer. Another solution was prepared by dissolving $100 \mathrm{mg}$ of AC in $20 \mathrm{~mL}$ of distilled water and $10 \mathrm{~mL}$ of ethanol and added to the former solution. The mixture was then transferred to Teflon crucible. The crucible with the mixture was then inserted to stainless steel autoclave for hydrothermal treatment at $130^{\circ} \mathrm{C}$ for $3 \mathrm{~h}$. After the hydrothermal reaction, the autoclave was cooled down to room temperature. After that, the product was filtered, washed with distilled water and ethanol several times. The sample was dried in an oven at $30^{\circ} \mathrm{C}$ for $12 \mathrm{~h}$ and $80^{\circ} \mathrm{C}$ for $6 \mathrm{~h}$, afterward. Then, the obtained product was called as $\mathrm{Fe}_{3} \mathrm{O}_{4} / \mathrm{AC}$ composite and was finally stored in polystyrene bottles for As adsorption.

\subsection{Batch Adsorption Experiments}

Batch studies were conducted to study As (III) adsorption onto the prepared composite. Adsorption experiment included the effect of process variables viz. contact time, $\mathrm{pH}$, adsorbent dose, and adsorption isotherm. A definite amount of composite adsorbent was placed in different $100 \mathrm{~mL}$ stoppered conical flask containing $25 \mathrm{~mL}$ of As (III) solution. The mixtures were agitated on an electric shaker (Digital VDRL Rotator) at $160 \mathrm{rpm}$ at room temperature. After equilibrium, the suspension was filtered, and As concentration in the filtrates before and after adsorption was determined by molybdenum blue method using spectrophotometer at $840 \mathrm{~nm}$. A calibration curve was constructed by plotting absorbance against concentrations of arsenic solution $(\mathrm{mg} / \mathrm{L})$. The concentration of arsenic $(\mathrm{mg} / \mathrm{L})$ of unknown solutions was measured using the calibration curve. For arsenic determination, atomic adsorption, SDDC (silver diethyldithiocarbamate), and molybdenum blue methods are widely used. Among them, the SDDC method and molybdenum blue methods are very fast, simple, reliable, and cost-effective. This method has a limit of the detection range of $1-50 \mu \mathrm{g} / \mathrm{L}$ in $5 \mathrm{~mL}$ solution [40].

Comparisons of percentage adsorption: Comparisons of adsorption percentage of As adsorptions onto plain AC and composite was studied with composite adsorbent and plain AC $1 \mathrm{~g} / \mathrm{L}$ respectively, initial concentration $5 \mathrm{mg} / \mathrm{L}$, contact time $60 \mathrm{~min}$ at $\mathrm{pH} 6.5$.

Effect of $\mathrm{pH}$ : Effect of $\mathrm{pH}$ on the percentage of As adsorption by the composite adsorbent was studied in the $\mathrm{pH}$ range of 2 to 11 . Other parameters, such as adsorbent dose $1 \mathrm{~g} / \mathrm{L}$, initial As concentration $5 \mathrm{mg} / \mathrm{L}$, and contact time $60 \mathrm{~min}$, were kept constant. The $\mathrm{pH}$ of the solution was adjusted by adding $0.1 \mathrm{~N} \mathrm{HCl}$ and $0.1 \mathrm{~N} \mathrm{NaOH}$. A pH of the solution was determined by using Digital $\mathrm{pH}$ meter, DICA, India.

Effect of dose: The effect of adsorbent dose on a percentage of As adsorption by composite adsorbent was studied by varying the adsorbent dose from $1 \mathrm{~g} / \mathrm{L}$ to $2.2 \mathrm{~g} / \mathrm{L}$. During the study, other parameters were kept constant, such as the initial As concentration $5 \mathrm{mg} / \mathrm{L}$, contact time $60 \mathrm{~min}$, and $\mathrm{pH} 6.5$.

Effect of contact time: The effect of contact time on the percentage of As adsorption by composite adsorbent was studied at different contact time from 5 to $140 \mathrm{~min}$. Other parameters were kept constant, such as the adsorbent dose $1 \mathrm{~g} / \mathrm{L}$, initial As concentration $5 \mathrm{mg} / \mathrm{L}$, and $\mathrm{pH}$ 6.5. All the experiments were carried out at room temperature. The percentage removal of As (III) adsorbed was calculated by using the following equation.

$$
\text { Removal percentage }=\frac{\left(C_{o}-C_{e}\right) \times 100}{C_{o}}
$$


where $C_{o}=$ Initial concentration of Arsenic $(\mathrm{mg} / \mathrm{L}) ; C_{e}=$ equilibrium concentration of Arsenic $(\mathrm{mg} / \mathrm{L})$.

Adsorption isotherms: Adsorption isotherms study was conducted with As solutions of different initial concentrations from $2 \mathrm{mg} / \mathrm{L}$ to $120 \mathrm{mg} / \mathrm{L}$. The other parameters were kept constant, such as adsorbent dose $1 \mathrm{~g} / \mathrm{L}$ and contact time $60 \mathrm{~min}$, during the experiment. The milligram of arsenic adsorbed per gram of adsorbent, $\mathrm{q}_{\mathrm{m}}(\mathrm{mg} / \mathrm{g})$, was calculated by using the following equation.

$$
\mathrm{q}_{\mathrm{m}}\left(\frac{\mathrm{mg}}{\mathrm{g}}\right)=\frac{\left(\mathrm{C}_{\mathrm{o}}-\mathrm{C}_{\mathrm{e}}\right) \times \mathrm{V}}{\mathrm{M}}
$$

where $\mathrm{V}=$ volume of As (III) solution (L) and $\mathrm{M}=$ mass of the adsorbent (g).

\section{Results and Discussion}

\subsection{Comparisons of Percentage Adsorption}

In the beginning, the removal percentage of As was evaluated by comparing the performances of the plain $\mathrm{AC}$ with respect to that of the $\mathrm{Fe}_{3} \mathrm{O}_{4} / \mathrm{AC}$ composite. Comparison of the percentage of As adsorption by plain activated carbon with the composite is presented in Figure 1.

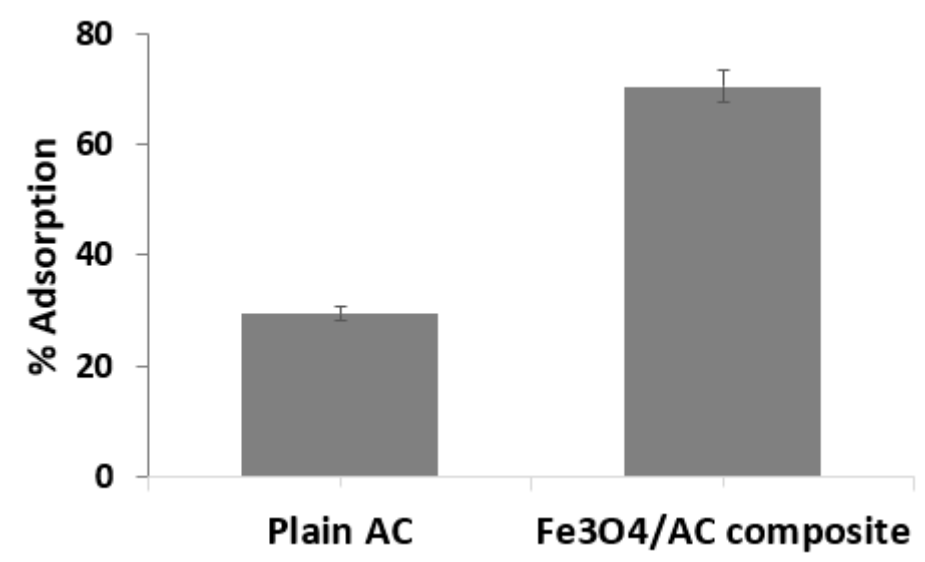

Figure 1. Percentage of As (III) adsorption by plain AC (activated carbon) and $\mathrm{Fe}_{2} \mathrm{O}_{3} / \mathrm{AC}$ composite with error bars.

The composite adsorbed As around $70 \%$ while plain AC adsorbed around $29 \%$. The result indicated that the prepared $\mathrm{Fe}_{3} \mathrm{O}_{4} / \mathrm{AC}$ composite was much more effective adsorbent than plain AC. It showed the synergistic effect of $\mathrm{AC}$ with $\mathrm{Fe}_{3} \mathrm{O}_{4}$ for the adsorption of arsenic. Compositing $\mathrm{AC}$ with iron resulted in the production of adsorption sites of $\mathrm{Fe}_{3} \mathrm{O}_{4}$ particles on the surface of AC. The adsorbed iron would coordinate with hydroxyl ions and neutral water molecules that are available in the aqueous solution. The adsorption of As (III) onto $\mathrm{Fe}_{3} \mathrm{O}_{4} / \mathrm{AC}$ composite surface took place through ligand exchange mechanism. The exchange process might involve ligands, such as hydroxyl ions or neutral water molecules, existing in the Fe-coordinated sphere. Hence, the adsorption of As (III) might take place by the release of a hydroxyl anion or neutral water molecules from its coordinated sphere. The mechanism that might be responsible for the adsorption of the arsenic anion is as follows [41].

$$
\begin{gathered}
\equiv \mathrm{FeOH}+\mathrm{H}_{3} \mathrm{AsO}_{3} \rightarrow \mathrm{FeH}_{2} \mathrm{AsO}_{3}+\mathrm{H}_{2} \mathrm{O} \\
\equiv 2[\mathrm{FeOH}]+\mathrm{H}_{3} \mathrm{AsO}_{3} \rightarrow \mathrm{FeHAsO}_{3} \mathrm{Fe}+2 \mathrm{H}_{2} \mathrm{O} \\
\equiv \mathrm{FeOH}+\mathrm{H}_{2} \mathrm{AsO}_{3}{ }^{-} \rightarrow \mathrm{FeHAsO}_{3}-+\mathrm{H}_{2} \mathrm{O} \\
\equiv 2[\mathrm{FeOH}]+\mathrm{H}_{2} \mathrm{AsO}_{3}{ }^{-} \rightarrow \mathrm{FeHAsO}_{3} \mathrm{Fe}+\mathrm{HO}-+\mathrm{H}+
\end{gathered}
$$


where $\equiv \mathrm{FeOH}$ represents the solid surface of $\mathrm{Fe}_{3} \mathrm{O}_{4} / \mathrm{AC}$ composite. Equations (3) and (4) represent adsorption of As (III) on the composite surface by monodentate ligand exchange, and Equations (5) and (6) represent bidentate ligand exchange with hydroxyl groups.

\subsection{Effect of $p H$}

Relative distribution of As, as well as ionization of functional groups on the adsorbent surface, depends on the $\mathrm{pH}$ of the solution [42]. Effect of $\mathrm{pH}$ on the percentage of adsorption of As (III) by the composite at different $\mathrm{pH}$ values is presented in Figure 2.

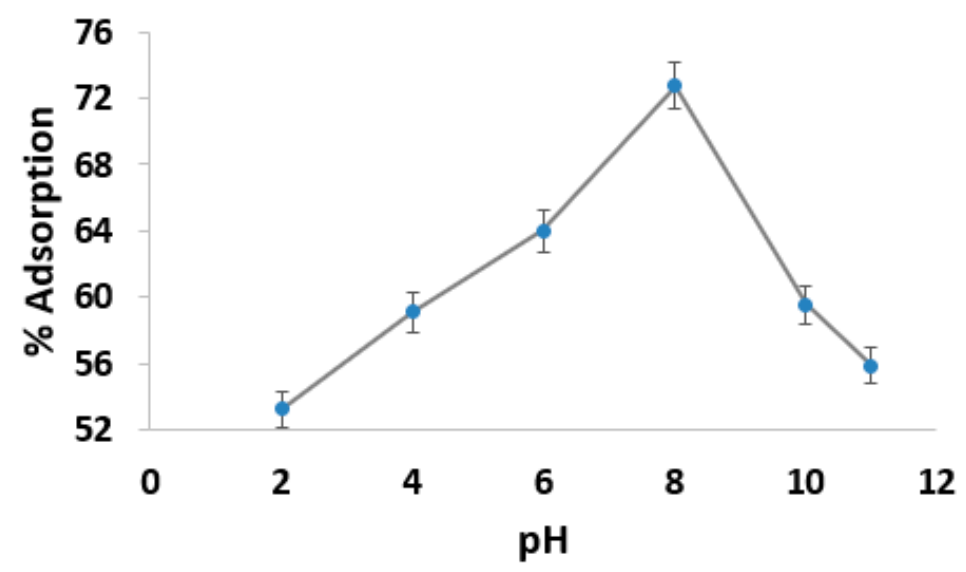

Figure 2. Effect of $\mathrm{pH}$ on the percentage of $\mathrm{As}(\mathrm{III})$ adsorption. Error bars represent the standard error from triplicate experiments.

It was observed that a sharp increase in the As removal occurred when the $\mathrm{pH}$ value of the solutions changed from 2 to 8 . From $\mathrm{pH} 8$ onwards, a decrease in the adsorption, of As ions, was achieved. The maximum adsorption, of As ions, was obtained at $\mathrm{pH}$ 8. Therefore, $\mathrm{pH} 8$ was considered as optimum $\mathrm{pH}$ for As (III) adsorption onto the composite. This adsorption behavior of As (III) at different $\mathrm{pH}$ might be due to the existence of As (III) in different oxyanions forms. In a highly acidic medium, As (III) mainly exists in the form of neutral $\mathrm{H}_{3} \mathrm{AsO}_{3}$ species, and the adsorbent surfaces are highly protonated so adsorption of As (III) is not favorable. This is probably due to the weak interaction that occurs between the composite surface and $\mathrm{H}_{3} \mathrm{AsO}_{3}$. At near neutral $\mathrm{pH}$ values of 7 to $9, \mathrm{H}_{3} \mathrm{AsO}_{3}$ could be deprotonated to form anionic species $\left(\mathrm{H}_{3} \mathrm{AsO}_{3}{ }^{-}\right.$and $\left.\mathrm{HAsO}_{3}{ }^{-}\right)$. This neutral $\mathrm{H}_{3} \mathrm{AsO}_{3}$ and negatively charged $\mathrm{H}_{2} \mathrm{AsO}_{3}{ }^{-}$and $\mathrm{HAsO}_{3}{ }^{2-}$ were attracted to the positively charged adsorbent surface. It resulted in high As (III) uptake by the adsorbent in this $\mathrm{pH}$ range. The adsorption of As (III) took place by substitution of the hydroxyl ions or water molecules contained in the coordination spheres of loaded metal ion from the adsorbent surface. The decrease in As (III) adsorption at $\mathrm{pH} 10$ might be due to the electrostatic repulsions between $\mathrm{H}_{2} \mathrm{AsO}_{3}{ }^{-}$and $\mathrm{HAsO}_{3}{ }^{2-}$ and the negatively charged composite surface. Thus, the combined effects of enhanced electrostatic repulsion and the hydroxyl ion competition were responsible for the decrease in arsenic As (III) adsorption at high pH. It reduced As (III) uptake by the composite. A similar observation has been reported for the removal of arsenic from aqueous solution using iron (III)-loaded sugarcane bagasse [43].

\subsection{Effect of Adsorbent Dose}

The effect of adsorbent dose on the adsorption of As by the composite is presented in Figure 3. It was observed that the percentage of As (III) adsorption increased with increase in adsorbent dose. It was mostly attributed to an increase in the adsorptive surface area and greater accessibility of surface binding sites to the composite adsorbent. Furthermore, the maximum As removal ( $75 \%)$ was recorded by $1.8 \mathrm{~g}$. After the dose of $1.8 \mathrm{~g} / \mathrm{L}$, it attained an equilibrium, and further addition did not change in the percentage of adsorption. This was due to the non-availability of active sites on 
the adsorbent resulting from overlapping or aggregation of adsorption sites and establishment of equilibrium between the As (III) on the composite and in the solution. Similar results were obtained for the removal of As (III) from aqueous solution using Fe (III)-loaded pomegranate waste [44].

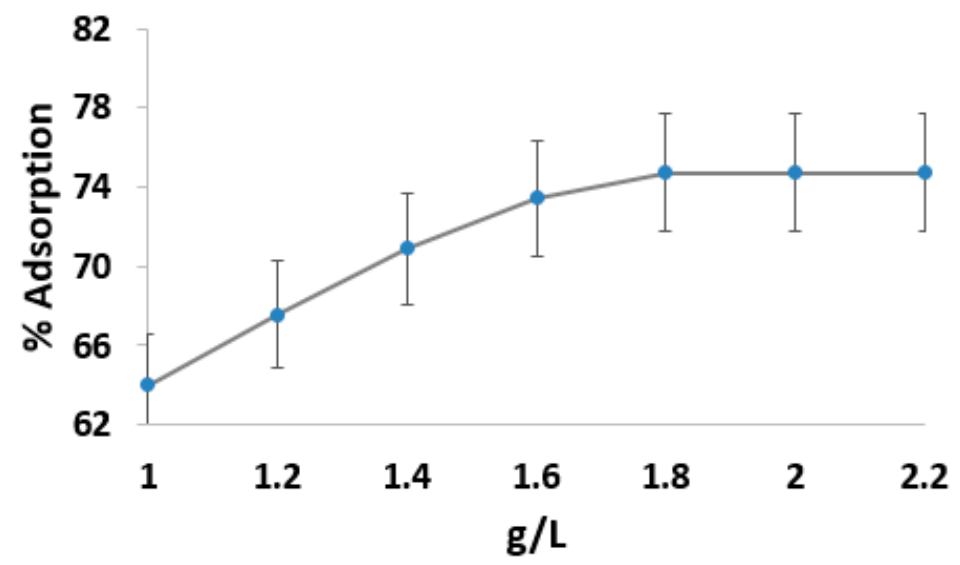

Figure 3. Effect of adsorbent dosage on the percentage of As (III) adsorption. Error bars represent the standard error from triplicate experiments.

\subsection{Effect of Contact Time}

Effect of contact time on the adsorption of As (III) by the composite is presented in Figure 4. Adsorption percentage was increased linearly from $5 \mathrm{~min}$ to $60 \mathrm{~min}$, and thereafter it remained almost constant, indicating the attainment of adsorption equilibrium. The adsorption rate was faster at initial stages that might be caused by a large number of available sites on the composite surface for As adsorption. The sorption rapidly occurs and is normally controlled by the diffusion process from the bulk to the surface. With the progress of time, the active sites are being saturated with more As (III) ions. It gives a decrease in the adsorption rate until the adsorption equilibrium is reached. Therefore, $60 \mathrm{~min}$ was chosen as the equilibrium time for As adsorption. Similar findings were observed by Yao et al. for As removal from aqueous solutions by adsorption onto iron oxide/AC magnetic composite [17].

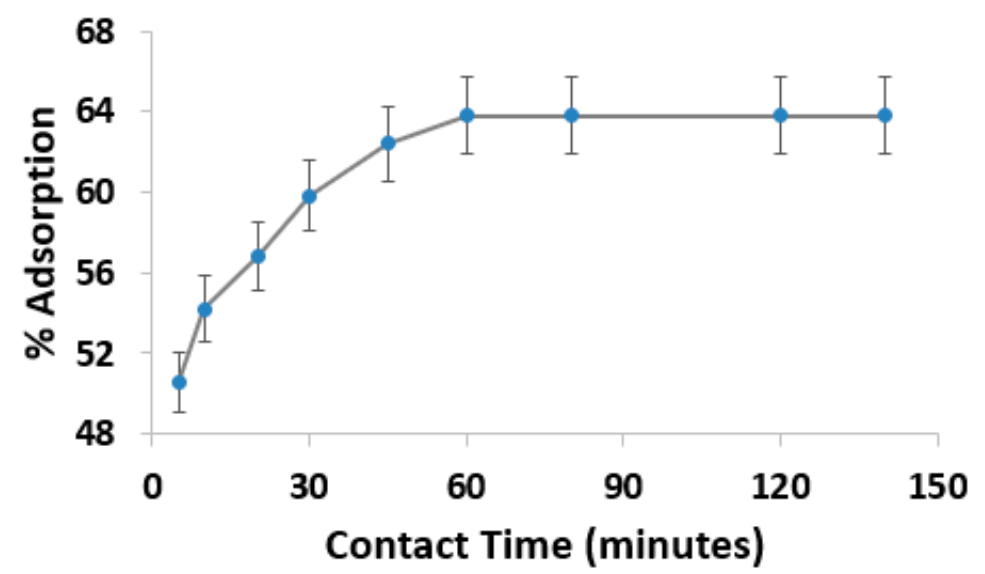

Figure 4. Effect of contact time on the percentage of As (III) adsorption. Error bars represent the standard error from triplicate experiments.

\subsection{Adsorption Isotherm}

Adsorption isotherm indicates the distribution of adsorbate molecules between the liquid phase and the solid phase when the adsorption process reaches an equilibrium state [45]. Mathematically, it is a curve that expresses the variation in the amount of adsorbate adsorbed by the adsorbent with its pressure or concentration at a constant temperature. Langmuir and Freundlich adsorption isotherms are 
commonly applied in solid/liquid system. The Langmuir describes the saturated monolayer adsorption on the homogenous surface, and there is no significant interaction among adsorbed species [46]. Freundlich adsorption isotherm describes the non-ideal adsorption on heterogeneous surface sites with different adsorption potential [47]. Equation (7) represents the linear form of the Langmuir adsorption model.

$$
\frac{\mathrm{C}_{\mathrm{e}}}{\mathrm{q}_{\mathrm{e}}}=\frac{1}{\mathrm{bq}_{\mathrm{m}}}+\frac{\mathrm{C}_{\mathrm{e}}}{\mathrm{q}_{\mathrm{m}}}
$$

where $\mathrm{q}_{\mathrm{m}}(\mathrm{mg} / \mathrm{g})$ is the maximum Langmuir adsorption capacity and $\mathrm{b}(\mathrm{L} / \mathrm{mg})$ is the Langmuir constant related to free energy. The Langmuir constants $\mathrm{q}_{\mathrm{m}}$ and $\mathrm{b}$ were calculated from the slope and intercept of the Langmuir plot.

Equation (8) represents the linear form of the Freundlich adsorption model.

$$
\log q_{e}=\log K+\frac{1}{n} \log C_{e}
$$

where $\mathrm{K}(\mathrm{mg} / \mathrm{g})$ is the Freundlich constant indicating adsorption capacity, $\mathrm{n}(\mathrm{L} / \mathrm{mg})$ is the adsorption intensity that is the measure of the change in the affinity of the adsorbate with the change in adsorption density. The Freundlich constants $\mathrm{K}$ and $\mathrm{n}$ were calculated from the slope and intercept of the Freundlich isotherm plot.

A Langmuir adsorption isotherm plot of $C_{e} / q_{e}$ versus $C_{e}$ for As adsorption is presented in Figure 5. Similarly, Freundlich adsorption isotherm for As adsorption plot is presented in Figure 6. In both graphs, the standard error bars are shown. The values of Langmuir and Freundlich parameters are given in Table 1. The applicability of the isotherm equation was compared by judging coefficients of determination $\left(\mathrm{R}^{2}\right)$ of Langmuir and Freundlich isotherm plots. The value of the coefficient of determination $\left(\mathrm{R}^{2}\right)$ of 0.991 for Langmuir isotherm was found to be higher as compared to Freundlich isotherm $\left(R^{2}\right)$ of 0.929 . This suggested that adsorption isotherm data better fitted the Langmuir isotherm. It means the number of active sites on the composite surface was limited, and a monolayer of As (III) was formed over the homogenous composite surface. The values of $1 / n$ lied between 0 and 1 , indicating the adsorption process was favorable.

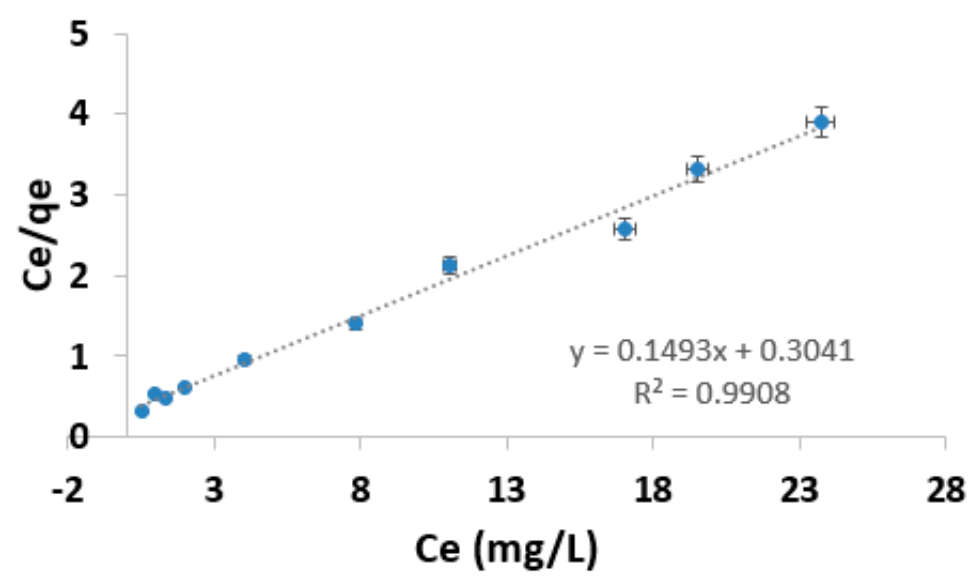

Figure 5. Langmuir isotherm for the adsorption of As (III) onto the composite with error bars.

Table 1. Langmuir and Freundlich parameters for the adsorption of As (III) onto the composite adsorbent.

\begin{tabular}{lccccccc}
\hline \multirow{2}{*}{ Species } & \multirow{2}{*}{ Adsorbent } & \multicolumn{3}{c}{ Langmuir Isotherm } & \multicolumn{3}{c}{ Freundlich Isotherm } \\
\cline { 3 - 7 } & & $\mathbf{q} \mathbf{m}(\mathbf{m g} / \mathbf{g})$ & $\mathbf{b}(\mathbf{L} / \mathbf{m g})$ & $\mathbf{R}^{\mathbf{2}}$ & $\mathbf{K}(\mathbf{m g} / \mathbf{g})$ & $\mathbf{1 / n}$ & $\mathbf{R}^{\mathbf{2}}$ \\
\hline \multirow{2}{*}{ As (III) } & AC composite & 6.69 & 0.491 & 0.991 & 2.293 & 0.353 & 0.929 \\
\hline
\end{tabular}




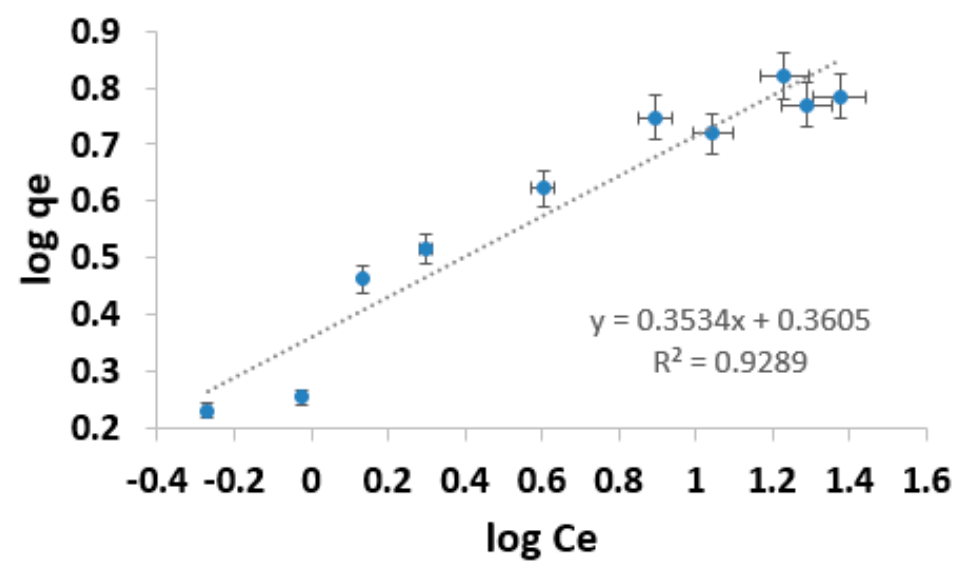

Figure 6. Freundlich isotherm for the adsorption of As (III) onto composite with error bars.

\subsection{Comparison of the Maximum Adsorption Capacity $\left(q_{m}\right)$ for As (III)}

The values of maximum adsorption capacity $\left(\mathrm{q}_{\mathrm{m}}\right)$ were also compared to that of other adsorbents. The comparison of maximum adsorption capacity $\left(\mathrm{q}_{\mathrm{m}}\right)$ of the composite with other previously reported adsorbents is presented in Table 2.

Table 2. Langmuir and Freundlich parameters for the adsorption of As (III) onto the composite.

\begin{tabular}{|c|c|c|}
\hline Adsorbents & Maximum Adsorption Capacity $\left(\mathrm{q}_{\mathrm{m}}\right)$ & References \\
\hline $\begin{array}{l}\text { Iron impregnated AC from } \\
\text { Lapsi seed stone }\end{array}$ & $2 \mathrm{mg} / \mathrm{g}$ & Rajbhandari R. [48] \\
\hline $\begin{array}{c}\text { Magnetic nanoparticles } \\
\text { obtained from metallic wool }\end{array}$ & $2.2 \mathrm{mg} / \mathrm{g}$. & Alarcon M. and Lopez M. [49] \\
\hline $\begin{array}{c}\text { Magnetite-maghemite } \\
\text { nanoparticles }\end{array}$ & $3.69 \mathrm{mg} / \mathrm{g}$ & Rahman S. and Yanful E. [50] \\
\hline $\begin{array}{c}\text { Iron oxide/commercial } \\
\text { activated carbon composite }\end{array}$ & $7.5 \mathrm{mg} / \mathrm{g}$ & Previous study [51] \\
\hline $\begin{array}{c}\text { Magnetic } \mathrm{Fe}_{3} \mathrm{O}_{4} / \text { sugarcane } \\
\text { Bagasse activated } \\
\text { carbon Composite }\end{array}$ & $6.69 \mathrm{mg} / \mathrm{g}$ & Present study \\
\hline
\end{tabular}

The composite adsorbent exhibited a greater As (III) adsorption capacity when compared to other reported adsorbents, such as magnetic nanoparticles obtained from metallic wool, magnetite-maghemite nanoparticles, and iron impregnated Lapsi seed stone AC. The adsorption capacity of the composite was comparable to magnetic $\mathrm{Fe}_{2} \mathrm{O}_{3}$ /commercial activated carbon composite. Hence, the result suggested that the prepared magnetic composite possessed higher potentiality towards the removal of As (III) from aqueous solution.

\section{Conclusions}

The removal of As (III) from aqueous solution by adsorption onto magnetic $\mathrm{Fe}_{3} \mathrm{O}_{4} /$ activated carbon composite prepared from sugarcane bagasse was studied. The performance of the composite was compared to those of plain AC. The percentage adsorption of the composite was much higher than the plain AC. The adsorption capacity of the composite for As (III) was dependent on the $\mathrm{pH}$, adsorbent dose, and contact time. The equilibrium data obtained from this study was fitted more to Langmuir isotherm than Freundlich isotherm. It indicated that the uptake of arsenic occurred on a homogenous surface of the composite by monolayer adsorption. The comparisons of maximum adsorption capacity of composite with earlier investigated adsorbents showed that the magnetic composite prepared in this work was an efficient adsorbent for the adsorptive removal of As (III) from aqueous solution. Thus, 
this magnetic composite adsorbent prepared from sugarcane bagasse showed significant potentiality towards the adsorptive removal of As (III) from aqueous solution.

Author Contributions: Conceptualization, B.S. and S.S.; methodology, S.J., M.S., and A.K.; formal analysis, B.S. and S.J.; writing-review and editing, B.S., S.J., and S.S.

Funding: This research received no external funding.

Acknowledgments: The authors gratefully acknowledge University Grants Commission (UGC) CRG 73/74-Engg-02, Nepal for financial support for this work. Also, the present research has been conducted by the Research Grant of Kwangwoon University in 2019.

Conflicts of Interest: The authors declare no conflict of interest.

\section{References}

1. Shankar, S.; Shikha, U. Arsenic Contamination of Groundwater: A Review of Sources, Prevalence, Health Risks, and Strategies for Mitigation. Sci. World J. 2014, 304524, 1-18. [CrossRef] [PubMed]

2. WHO. Guidelines for Drinking Water Quality; World Health Organization: Geneva, Switzerland, 1996; Volume 2, pp. 940-949.

3. Huq, S.M.I.; Joardar, J.C.; Parvin, S.; Correll, R.; Naidu, R. Arsenic Contamination in Food Chain: Transfer of Arsenic into Food Materials through Groundwater Irrigation. J. Healthpopul. Nutr. 2006, 24, 305-316.

4. Pokhrel, D.; Bhandari, B.S.; Viraraghavan, T. Arsenic contamination of groundwater in the Terai region of Nepal: An overview of health concerns and treatment options. Environ. Int. 2009, 35, 157-161. [CrossRef] [PubMed]

5. Shrestha, R.K.; Regmi, D.; Kafle, B.P. Seasonal variation of arsenic concentration in groundwater of Nawalparasi district of Nepal. Int. J. Appl. Sci. Biotechnol. 2014, 2, 59-63. [CrossRef]

6. Thakur, J.K.; Thakur, R.K.; Ramanathan, A.L.; Kumar, M.; Singh, S.K. Review Arsenic Contamination of Groundwater in Nepal-An Overview. Water 2011, 3, 1-20. [CrossRef]

7. Mueller, B. Preliminary trace element analysis of arsenic in Nepalese groundwater may pinpoint its origin. Environ. Earth Sci. 2018, 77, 1-6. [CrossRef]

8. Jang, Y.C.; Somann, S.; Kim, H. Distribution, Toxicity and Remediation of Arsenic in the Environment-A review. Int. J. Appl. Environ. Sci. 2016, 11, 559-581.

9. Mueller, B. Ground Water Contamination by Arsenic in Nepal: Lessons to be Learned from Geology. Austin Chem. Eng. 2019, 6, 1064.

10. Hong, Y.S.; Song, K.H.; Chung, J.Y. Health Effects of Chronic Arsenic Exposure. J. Prev. Med. Public Health 2014, 47, 245-252. [CrossRef]

11. Leupin, O.X.; Hug, S.J. Oxidation and removal of arsenic (III) from aerated groundwater by filtration through sand and zero-valent iron. Water Res. 2005, 39, 1729-1740. [CrossRef]

12. Bose, P.; Sharma, A. Role of iron in controlling speciation and mobilization of arsenic in subsurface environment. Water Res. 2002, 36, 4916-4926. [CrossRef]

13. Masue, Y.; Loeppert, R.H.; Kramer, T.A. Arsenate and arsenite adsorption and desorption behavior on coprecipitated aluminum: Iron hydroxides. Environ. Sci. Technol. 2007, 41, 837-842. [CrossRef] [PubMed]

14. Banerjee, K.; Amy, G.L.; Prevost, M. Kinetic and thermodynamic aspects of adsorption of arsenic onto granular ferric hydroxide (GFH). Water Res. 2008, 42, 3371-3378. [CrossRef] [PubMed]

15. Sperlich, A.; Werner, A.; Genz, A.; Amy, G.; Worch, E.; Jekel, M. Breakthrough behavior of granular ferric hydroxide (GFH) fixed-bed adsorption filters: Modeling and experimental approaches. Water Res. 2005, 39, 1190-1198. [CrossRef] [PubMed]

16. Yoon, J.; Amy, G.; Chung, J.; Sohn, J.; Yoon, Y. Removal of toxic ions (chromate, arsenate, and perchlorate) using reverse osmosis, nanofiltration, and ultrafiltration membranes. Chemosphere 2009, 77, 228-235. [CrossRef]

17. Yao, S.; Liu, Z.; Shi, Z. Arsenic removal from aqueous solutions by adsorption onto iron oxide/activated carbon magnetic composite. J. Environ. Health Sci. Eng. 2014, 12, 58. [CrossRef]

18. Medina-Ramirez, A.; Beatriz, R.C.P.; Minchaca-Mojica, J.I.; Romero-Toledo, R.; Gamero-Vega, K.Y. Adsorption of Aqueous As (III) in Presence of Coexisting Ions by a Green Fe-Modified W Zeolite. Water 2019, 11, 281. [CrossRef] 
19. Mohan, D.; Pittman, C.U. Arsenic removal from water/wastewater using adsorbents-A critical review. J. Hazard. Mater. 2007, 142, 1-53. [CrossRef]

20. Aredes, S.; Klein, B.; Pawlik, M. The removal of arsenic from water using natural iron oxide minerals. J. Clean. Prod. 2012, 29-30, 208-213. [CrossRef]

21. Polowczyk, I.; Cyganowski, P.; Ulatowska, J.; Sawiński, W.; Bastrzyk, A. Synthetic Iron Oxides for Adsorptive Removal of Arsenic. Water Air Soil Pollut. 2018, 229, 203. [CrossRef]

22. Zhang, Q.L.; Gao, N.Y.; Lin, Y.C.; Xu, B.; Le, L.S. Removal of Arsenic(V) from Aqueous Solutions Using Iron-Oxide-Coated Modified Activated Carbon. Water Environ. Res. 2007, 79, 931-936. [CrossRef] [PubMed]

23. Muller, K.; Ciminelli, V.S.T.; Dantas, M.S.S.; Willscher, S. A comparative study of As(III) and As(V) in aqueous solutions and adsorbed on iron oxyhydroxides by Raman Spectroscopy. Water Res. 2010, 44, 5660-5672. [CrossRef] [PubMed]

24. Wannahari, R.; Sannasi, P.; Nordin, M.F.M.; Mukhtar, H. Sugarcane bagasse derived nano magnetic adsorbent composite (SCB-NMAC) for removal of $\mathrm{Cu}^{2+}$ from aqueous solution. ARPN J. Eng. Appl. Sci. 2018, 13, 1-9.

25. Kakavandi, B.; Kalantary, R.R.; Farzadkia, M.; Mahvi, A.H.; Esrafili, A.; Azari, A.; Yari, A.R.; Javid, A.B. Enhanced chromium (VI) removal using activated carbonmodified by zero valent iron and silver bimetallic nanoparticles. J. Environ. Health Sci. Eng. 2014, 12, 115. [CrossRef] [PubMed]

26. Gholamvaisi, D.; Azizian, S.; Cheraghi, M. Preparation of magnetic-activated carbon nanocomposite and its application for dye removal from aqueous solution. J. Dispers. Sci. Technol. 2014, 35, 1264-1269. [CrossRef]

27. Affam, A.C.; Wong, C.C.; Seyam, M.A.B.; Matt, C.A.A.F.; Sumbai, J.L.A.; Evuti, A.M. Preparation, characterization and adsorption study of granular activatedcarbon/iron oxide composite for the removal of boron and organics from wastewater. E3S Web Conf. 2018, 34, 02006. [CrossRef]

28. Yao, S.; Sun, S.; Wang, S.; Shi, Z. Adsorptive removal of lead ion from aqueous solution by activated carbon/iron oxide magnetic composite. Indian J. Chem. Technol. 2016, 23, 146-152.

29. Liang, S.Z.; Mei, L.F.; Hua, Y.S. Adsorptive removal of phosphate from aqueous solutions using activated carbon loaded with Fe(III) oxide. New Carbon Mater. 2011, 26, 299-306.

30. Castro, C.S.; Guerreiro, M.S.; Goncalves, M.; Oliveira, L.C.A.; Anastácio, A.S. Activated carbon/iron oxide composites for the removal of atrazine from aqueousmedium. J. Hazard. Mater. 2009, 164, 609-614. [CrossRef] [PubMed]

31. Oliveira, L.C.A.; Rios, R.V.R.A.; Fabris, J.D.; Garg, V.; Sapag, K.; Lago, R.M. Activated carbon/iron oxide magnetic composites for the adsorption of contaminants inwater. Carbon 2002, 40, 2177-2183. [CrossRef]

32. Faulconer, E.K.; Hoogesteijn, N.V.V.R.; Mazyck, D.W. Optimization of magnetic powdered activated carbon for aqueous $\mathrm{Hg}$ (II) removal and magnetic recovery. J. Hazard. Mater. 2012, 199-200, 9-14. [CrossRef] [PubMed]

33. Tan, K.A.; Morad, N.; Teng, T.T.; Norli, I.; Panneerselvam, P. Removal of cationic dye by magnetic nanoparticle $\left(\mathrm{Fe}_{3} \mathrm{O}_{4}\right)$ impregnated onto activated maize cobpowder and kinetic study of dye waste adsorption. APCBEE Procedia 2012, 1, 83-89. [CrossRef]

34. Iqbal, H.M.N.; Kyazze, G.; Keshavarz, T. Advances in the valorization of lignocellulosic materials by biotechnology: An overview. Bioresources 2013, 8, 2. [CrossRef]

35. Debalina, B.; Reddy, R.B.; Vinu, R. Production of carbon nanostructures in biochar, bio-oil and gases from bagasse via microwave assisted pyrolysis using Fe and Co as susceptors. J. Anal. Appl. Pyrolysis 2017, 24, 310-318. [CrossRef]

36. Siddiqui, M.T.H.; Nizamuddin, S.; Baloch, H.A.; Mubarak, N.M.; Dumbre, D.K.; Inamuddin, A.M.A.; Bhutto, A.W.; Srinivasan, M.; Griffin, G.J. Synthesis of magnetic carbon nanocomposites by hydrothermal carbonization and pyrolysis. Environ. Chem. Lett. 2018, 16, 821-844. [CrossRef]

37. Yang, N.; Zhu, S.; Zhang, D.; Xu, S. Synthesis and properties of magnetic $\mathrm{Fe}_{3} \mathrm{O}_{4}$-activated carbon nanocomposite particles for dye removal. Mater. Lett. 2008, 62, 645-647. [CrossRef]

38. Seabra, J.E.A.; Tao, L.; Chum, H.L.; Macedo, I.C. A techno-economic evaluation of the effects of centralized cellulosic ethanol and co-products refinery options with sugarcane mill clustering. Biomass Bioenergy 2010, 34, 1065-1078. [CrossRef]

39. Neupane, P.R.; Maraseni, T.N.; Koehl, M. The sugarcane industry in Nepal: Opportunities and challenges. Environ. Dev. 2017, 24, 86-98. [CrossRef]

40. Sandell, E.B. Colorimetric Determination of Traces of Metals; Interscience Publisher: New York, NY, USA, 1959; pp. 1906-1984. 
41. Mahmood, T.; Aslam, M.; Naeem, A.; Siddique, T.; Din, S.U. Adsorption of As(III) from aqueous solution onto iron impregnated used tea activated carbon: Equilibrium, kinetic and thermodynamic study. J. Chil. Chem. Soc. 2018, 63, 3855-3866. [CrossRef]

42. Agrawal, S.; Singh, N.B. Removal of arsenic from aqueous solution by an adsorbent nickel ferrite-polyaniline nanocomposite. Indian J. Chem. Technol. 2016, 5, 374-383.

43. Thakuri, H.C.; Pokhrel, M.R.; Ghimire, K.N.; Khadka, D.B. Removal of Arsenic from Aqueous Solution Using Iron(III)-loaded Sugarcane Bagasse. Res. J. Chem. Sci. 2015, 11, 51-58.

44. Thapa, S.; Pokhrel, M.R. Removal of As(III) from Aqueous Solution Using Fe(III) Loaded Pomegranate Waste. J. Nepal Chem. Soc. 2012, 30, 29-36. [CrossRef]

45. Inyinbor, A.A.; Adekola, F.A.; Olatunji, G.A. Kinetics, isotherms and thermodynamic modeling of liquid phase adsorption of Rhodamine B dye onto Raphia hookerie fruit epicarp. Water Resour. Ind. 2016, 15, 14-27. [CrossRef]

46. Das, B.; Mondal, N.K.; Bhaumik, R.; Roy, P. Insight into adsorption equilibrium, kinetics and thermodynamics of lead onto alluvial soil. Int. J. Environ. Sci. Technol. 2014, 11, 1101-1114. [CrossRef]

47. Ayawei, N.; Ebelegi, A.N.; Wankasi, D. Modelling and Interpretation of Adsorption Isotherms. J. Chem. 2017, 2017, 3039817. [CrossRef]

48. Rajbhandari, R. Preparation and Characterization of Activated Carbon from Lapsi (Choerospondias axillaris) Seed Stone for the Removal of Arsenic (iii) from Water. Ph.D. Thesis, Department of Engineering Science and Humanities, Pulchowk Campus, Tribhuvan University, Lalitpur, Nepal, 2014.

49. Alarcon, M.; Lopez, M. Technical feasibility of using magnetic nanoparticles obtained from metallic wool for arsenite (As (III)) removal from aqueous solutions. J. Nanosci. Technol. 2016, 4, 35-43.

50. Rahman, S.; Yanful, E. Arsenic and chromium removal by mixed magnetite-maghemite nanoparticles and the effect of phosphate on removal. J. Environ. Manag. 2010, 11, 2238-2247.

51. Joshi, S.; Kumari, A.; Banjara, A.; Sharma, M. Use of iron oxide/activated carbon magnetic composite for adsorptive removal of arsenic from water. Int. J. Adv. Eng. 2019, 1, 9-16.

(C) 2019 by the authors. Licensee MDPI, Basel, Switzerland. This article is an open access article distributed under the terms and conditions of the Creative Commons Attribution (CC BY) license (http://creativecommons.org/licenses/by/4.0/). 